\begin{tabular}{|c|c|}
\hline Title & Bromoform concentrations in slush-layer water in A ntarctic fast ice \\
\hline Author(s) & Nomura, Daiki; Ooki, A tsushi; Simizu, Daisuke; Fukuchi, Mitsuo \\
\hline Citation & $\begin{array}{l}\text { A ntarctic Science, 23(6), 623-628 } \\
\text { https://doi.org/10.1017/S0954102011000459 }\end{array}$ \\
\hline Issue Date & 2011-11-22 \\
\hline Doc URL & http:/hdl.handle.net/2115/70578 \\
\hline Rights & $\begin{array}{l}\text { This article has been published in a revised form in A ntarctic Science https://doi.org/10.1017/50954102011000459. } \\
\text { This version is free to view and download for private research and study only. Not for re distribution, re sale or use in } \\
\text { derivative works. } \odot 2011 \text { A ntarctic Science Ltd }\end{array}$ \\
\hline Type & article (author version) \\
\hline File Information & A ntarctic_Science_23_6(2011).pdf \\
\hline
\end{tabular}

Instructions for use 


\section{Bromoform concentrations in slush-layer water in Antarctic fast ice}

2

3

4 Daiki Nomura $^{\mathrm{a} 1 \mathrm{a} 2 \mathrm{a} 3 \mathrm{c} 1}$, Atsushi Ooki $^{\mathrm{a} 4}$, Daisuke Simizu ${ }^{\mathrm{a} 5}$ and Mitsuo Fukuchi ${ }^{\mathrm{a} 1}$

5

6

7

8

9

10

11

12

13

14

15

16

17

18

19

20

21

22

$23{ }^{\mathrm{c}}$ Corresponding author. Present address: Norwegian Polar Institute, The Polar

24 Environmental Centre, Tromsø, NO-9296, Norway. E-mail: daiki.nomura@npolar.no 25

26

27

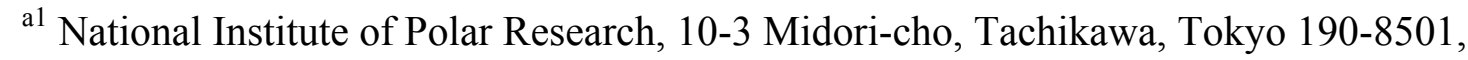
Japan

${ }^{a} 2$ Norwegian Polar Institute, The Polar Environmental Centre, Tromsø, NO-9296,

Norway

a3 Japan Society for the Promotion of Science, 6 Ichiban-cho, Chiyoda, Tokyo 102-8471, Japan

${ }^{\mathrm{a} 4}$ National Institute for Environmental Studies, 16-2, Onogawa, Tsukuba, Ibaraki 3050053, Japan

${ }^{\text {a5 }}$ Institute of Low Temperature Science, Hokkaido University, Kita-19, Nishi-8, Kitaku, Sapporo, Hokkaido 060-0819, Japan 
28 Abstract:

29 Bromoform concentrations in water of the slush layer that developed at the interface

30 between snow and sea ice were measured during the seasonal warming in Lützow-Holm

31 Bay, Eastern Antarctica. Mean bromoform concentration was $5.5 \pm 2.4 \mathrm{pmol}^{-1}$, which

32 was lower than that of the under-ice water $\left(10.9 \pm 3.5 \mathrm{pmol} \mathrm{l}^{-1}\right)$. Temporal decrease in

33 bromoform concentrations and salinity with increasing in temperature of the slush water

34 suggest that the bromoform concentrations were reduced through dilution with

35 meltwater input from the upper surface of sea ice. In contrast, bromoform

36 concentrations in the under-ice water increased during this period while the salinity of

37 the under-ice water decreased. It is speculated that the sea ice meltwater input contained

38 high bromoform concentrations from the brine channels within the sea ice and from the

39 bottom of the ice that were contributed to the increased bromoform concentrations in

40 the under-ice water.

41

42

43 Key words: bromoform, sea ice, slush layer, under-ice water, Lützow-Holm Bay 44 
49 Bromoform $\left(\mathrm{CHBr}_{3}\right)$ is one of the volatile organic compounds (VOCs) originating with

50 macroalgal and planktonic sources in the ocean, and bromoform is emitted from the ocean surface to the atmosphere (Quack \& Wallace 2003). Bromoform is an important carrier of bromine to the troposphere, and its lifetime in the atmosphere is one to four weeks (Quack \& Wallace 2003 and references therein). Although bromoform concentrations in the ocean have been measured widely, there is a lack of information regarding measurements of brimoform in the ice-covered seas. Sea ice may be a significant platform for the production of bromine compounds and a source for the atmosphere (Sturges et al. 1992, 1993, 1997, Carpenter et al. 2007). For example, polar ice algae is known to produce significant quantities of bromoform (Sturges et al. 1992).

A surface slush layer (gap layer) is found extensively in Antarctic sea ice during the ice melting season (Haas et al. 2001, Kattner et al. 2004, Ackley et al. 2008, Zemmelink et al. 2008, Papadimitriou et al. 2009). Snow accumulation over sea ice and the formation of superimposed ice leads to the formation of a slush layer below sea level (Haas et al. 2001). High biological activity has been found in this layer (Kattner et al. 2004), suggesting that bromoform production could also be high in this layer. In addition, bromoform produced in the slush layer would accumulate because of limited gas diffusion through the snow and superimposed ice (Delille 2006, Nomura et al. 2010).

The bromoform dynamics in the sea ice column has been well studied (Sturges et al. 1993, 1997). From these studies, it is clear that the biogenic production of bromoform by ice algae could be an important contributor to atmospheric bromoform levels in the polar regions (e.g., Sturges et al. 1992). However, although slush water is expected to potentially include the highest levels of bromoform in surface ice, bromoform concentrations in slush water have not yet been examined. In addition, it is not clear which processes dominate the temporal variability of bromoform concentrations in slush water. 
In this study, we examined for the first time the magnitude and temporal variations of bromoform concentrations in slush water, and their links to the physical and biogeochemical parameters of slush water and sea ice. Our results should provide an important insight into the organic bromine cycle in ice-covered seas.

\section{Materials and methods}

Slush-water samples were collected in the austral spring/summer (26 December 2009 to 5 February 2010) from the multi-year land-fast ice in Lützow-Holm Bay, Eastern Antarctica (Fig. 1). During this period, several sampling stations were established within a $0.5-\mathrm{km}^{2}$ area. Under-ice water was also collected from the same area.

For slush-water sampling, snow and superimposed ice were removed with a scoop, and ice crystals in the slush layer were removed with a net. The water in the slush layer was pumped through a Teflon tube by a diaphragm pump (EWP-01, As One Corporation, Osaka, Japan) and collected in a 30-ml amber glass vial (Nichiden-Rika Glass Co. Ltd, Kobe, Japan). Mercuric chloride solution (Saturated- $\mathrm{HgCl}_{2} ; 200 \mu \mathrm{l}$ ) was added to the samples to stop biological activity. Vials were sealed with a Teflon-lined septum (Nichiden-Rika Glass Co. Ltd) and an aluminum cap (Nichiden-Rika Glass Co. Ltd). Slush-water samples were stored in a refrigerator $\left(+4{ }^{\circ} \mathrm{C}\right)$ until further analysis. To check the spatial heterogeneity of slush water, duplicate samplings were carried out for slush water within $2 \mathrm{~m}^{2}$ on each sampling day.

For under-ice water sampling, a hole was made using an ice corer (Geo Tecs Co., Ltd., Chiba, Japan) with an internal diameter of $9.0 \mathrm{~cm}$, and under-ice water was collected with a Teflon water sampler (GL Science Inc., Tokyo, Japan) at 1 and $7 \mathrm{~m}$ below the bottom of the sea ice. Under-ice water samples were collected approximately 30 minutes after drilling of the ice cores to avoid the effects of the disturbance caused by drilling. Samples were treated and stored in the same manner as for slush-water samples. 
109 The temperature of the slush and under-ice water was measured using a needle-type

110 temperature sensor (Testo 110 NTC, Brandt Instruments, Inc., Prairieville, LA, USA).

111 Slush and under-ice water samples were also collected and placed into 12-ml glass

112 screw-cap vials (Nichiden-Rika Glass Co. Ltd) for salinity analysis, and into 500-ml

113 Nalgene polycarbonate bottles (Thermo Fisher Scientific Inc., Waltham, MA, USA) for

114 chlorophyll $a$ (chl- $a$ ) measurement. Salinity samples were kept in a refrigerator $\left(+4{ }^{\circ} \mathrm{C}\right)$.

115 The seawater samples for chl- $a$ analysis were filtered through $25-\mathrm{mm}$ Whatman GF/F

116 filters immediately after returning to the laboratory near the sampling station.

117 Chlorophyll pigments on the filters were extracted in dimethylformamide (Suzuki \&

118 Ishimaru 1990) for $24 \mathrm{~h}$ at approximately $-80^{\circ} \mathrm{C}$.

120 The bromoform concentrations were determined by a purge-and-trap (P\&T) and gas121 chromatograph-mass spectrometry (GC-MS) method (Yokouchi et al. 2006, Ooki \&

122 Yokouchi 2011a, Ooki \& Yokouchi 2011b). The total volume of seawater in the sample

123 bottle was transferred to a custom-made bubbling vessel by helium carrier at $40 \mathrm{ml} \mathrm{min}$

124 . The dissolved bromoform in the water was purged with the helium carrier at $80 \mathrm{ml}$

$125 \mathrm{~min}^{-1}$ and $45^{\circ} \mathrm{C}$ for $30 \mathrm{~min}$, and simultaneously transferred to a pre-concentration-GC-

126 MS system (Agilent 5973, 6390; Agilent Technologies Inc., Santa Clara, CA, USA)

127 (Yokouchi et al. 2006, Ooki \& Yokouchi 2011a, Ooki \& Yokouchi 2011b). The purge

128 efficiency for bromoform was $84 \%$. A diluted standard solution containing bromoform

129 at $1.2 \mathrm{pmol}^{-1}$ was introduced to the P\&T-GC-MS system every $24 \mathrm{~h}$ to calibrate for the

130 bromoform concentrations in seawater samples. The precision of standard solution

131 measurements was $\pm 2 \%(n=4)$, and the detection limit $(\mathrm{S} / \mathrm{N}=10)$ was $0.4 \mathrm{pmol}^{-1}$.

133 Salinity was measured with a salinity analyzer (SAT-210, Toa Electronics Ltd., Tokyo,

134 Japan). The salinity analyzer was calibrated with International Association for the

135 Physical Science of the Ocean standard seawater (P series; Ocean Scientific

136 International Ltd., Hampshire, UK). Chl- $a$ concentrations were determined using a

137 fluorometer (Model 10AU, Turner Designs, Inc., Sunnyvale, CA, USA), following

138 methods described by Parsons et al. (1984). 


\section{$141 \quad$ Results}

\section{Bromoform and chl-a concentrations, salinity and temperature}

145 Bromoform and chl- $a$ concentrations, salinity and temperature in slush and under-ice

146 water obtained during the study period are summarized in Table 1 . The mean

147 bromoform concentration in slush water was $5.5 \mathrm{pmol}^{-1}$, which was lower than that of

148 under-ice water $\left(10.9 \mathrm{pmol}^{-1}\right)$. In contrast, the mean chl- $a$ concentration in slush water

$149\left(0.4 \mu \mathrm{g}^{-1}\right)$ was approximately double that of under-ice water $\left(0.2 \mu \mathrm{g}^{-1}\right)$. The mean

150 salinity of the slush water (9.7) was approximately one-third that of the under-ice water

151 (32.5). The mean temperature of the slush water $\left(+0.5^{\circ} \mathrm{C}\right)$ was higher than that of the

152 under-ice water $\left(-0.4^{\circ} \mathrm{C}\right)$ due to the downward flushing of meltwater from the top,

153 which was generated by the melting of the snow on sea ice at higher air temperature

154 (Fig. 2). Although the range of values for some of these parameters includes temporal

155 variations during the study period, the slush water was consistently characterized by

156 lower bromoform concentrations and lower salinity compared to the under-ice water

157 (Table 1).

160 Temporal variations in bromoform and chl-a concentrations, salinity and temperature

161

162 Sampling occurred from late spring (26 December) to mid summer (5 February),

163 providing an opportunity to observe temporal variations of physico-chemical properties

164 during warming and ice-melting conditions (Fig. 2). The snow depth over the sea ice

165 decreased from $100 \mathrm{~cm}$ at the beginning of this period to less than $10 \mathrm{~cm}$ at the end,

166 whereas ice thickness was almost constant during the period $(176 \pm 25 \mathrm{~cm})$. There was a

167 layer of superimposed ice (about $10 \mathrm{~cm}$ thick) between the snow and slush layers during

168 the sampling period. 
170 Temporal variations in bromoform and chl- $a$ concentration, salinity and temperature in

171 slush and under-ice water were shown in Figure 3. Bromoform concentrations in the

172 slush water were relatively constant $\left(8-9\right.$ pmol $\left.^{-1}\right)$ until 5 January, and then they

173 decreased to below $5 \mathrm{pmol}^{-1}$ and remained constant for the rest of the sampling period

174 (Fig. 3a). The salinity of the slush water decreased dramatically from 28.6 on 26

175 December to 0.8 on 2 February (Fig. 3e). On the other hand, the slush-water

176 temperature increased from $-1.9{ }^{\circ} \mathrm{C}$ to $+2.6{ }^{\circ} \mathrm{C}$ during the study period (Fig. $3 \mathrm{~g}$ ). The

177 trends of decrease in salinity and increase in temperature of slush water were similar to

178 that of bromoform concentrations during this period (Figs. 3a, e \& g), with the

179 bromoform concentrations being correlated with the salinity (shown in Figure 4), and

180 with the temperature of slush water $(r=0.78, P<0.0001, n=22)$. For the relationship

181 between salinity and bromoform concentrations in slush water (Fig. 4), there were two

182 different regimes: 1) the decrease in bromoform concentrations in the slush water only

183 holds until a decrease in salinity to around 5,2) at lower salinity (salinity $<5$ ), the

184 bromoform concentration in slush water increased to $5.9 \mathrm{pmol}^{-1}$ with decreasing

185 salinity. Chl- $a$ concentrations in slush water varied between 0.0 and $1.1 \mu \mathrm{g} 1^{-1}$ (Fig. $3 \mathrm{c}$ ),

186 and were not correlated with the changes in bromoform concentrations $(r=0.09, P=$

$1870.68, n=22)$.

188

189 Concentrations of bromoform in under-ice water $\left(5-18 \mathrm{pmol}^{-1}\right)$ were higher compared

190 with the slush-water concentrations (Figs. 3a \& b). Chl- $a$ concentrations in under-ice

191 water remained low $\left(<0.3 \mathrm{pmol}^{-1}\right)$ until 14 January, and then they gradually increased

192 (Fig. 3d). Salinity of under-ice water decreased from about 34 early in the study period

193 (26 December-5 January) to below 30 at the end (29 January-5 February) (Fig. 3f). The

194 temperature of under-ice water increased slightly during the study period (Fig. 3h).

195 There were no notable differences between the under-ice water at $1 \mathrm{~m}$ and $7 \mathrm{~m}$ for any

196 of the parameters during the study period (Figs. 3b, d, f \& h).

197

198

199 Discussion

200 
201 The bromoform concentrations in under-ice water measured in this study (5.9-18.3

$202 \mathrm{pmol}^{-1}$ ) were lower than those of Arctic under-ice water in spring (about $80 \mathrm{pmol} \mathrm{l}^{-1}$;

203 Sturges et al. 1997) and coastal Antarctic surface water in spring/summer (about 57

$204 \mathrm{pmol}^{-1}$; Carpenter et al. 2007). The higher bromoform concentrations previously

205 measured in polar seawater were caused by inputs of ice meltwater containing high

206 levels of bromoform produced by ice algae, or by in situ production of bromoform in

207 the seawater during algae blooms (e.g., Sturges et al. 1992, Carpenter et al. 2007). The

208 increasing levels of bromoform in the ocean have generally been associated with the

209 increasing abundance of diatoms (Klick \& Abrahamsson 1992, Baker et al. 1999). An

210 in situ culture experiment has shown that Arctic ice algae have the potential to produce

211 substantial quantities of bromoform at high chl- $a$ concentrations $\left(>700 \mu \mathrm{g}{ }^{-1}\right)$ within

212 the bottom layer of sea ice (Sturges et al. 1992). However, because chl- $a$ concentrations

213 were generally low during our study (mean, $0.2 \mu \mathrm{g}^{-1}$ ), the contribution of ice algae to

214 bromoform production would have been minor. This is likely to be one of reasons why

215 bromoform concentration in under-ice water in this study were so much lower than

216 those of previous studies (Sturges et al. 1992, Carpenter et al. 2007).

217

218 A surface slush layer is found widely distributed in Antarctic sea ice during the ice

219 melting season (Haas et al. 2001, Kattner et al. 2004, Ackley et al. 2008, Zemmelink et

220 al. 2008, Papadimitriou et al. 2009). Snow accumulation over sea ice and the formation

221 of superimposed ice leads to the formation of a slush layer below sea level (Haas et al.

222 2001). In this layer, high biological activity has been found (Kattner et al. 2004),

223 suggesting that the biogenic production of bromoform should also be high in this layer.

224 However, in this study we found chl- $a$ concentrations in the slush layer (mean $0.4 \mu \mathrm{g} \mathrm{l}^{-}$

225 1; Table 1) to be much lower than those in the productive slush layer in the Weddell Sea,

226 Antarctica (3.1-16.5 $\mu \mathrm{g} \mathrm{1^{-1 }}$; Kattner et al. 2004). Snow depth was basically high (mean

$22724 \mathrm{~cm}$ ) compared to those in the Weddell Sea, Antarctica (mean $16 \mathrm{~cm}$; Kattner et al.

228 2004). These results suggest the reduction of the light intensity in the slush layer,

229 thereby reducing the light available for growth of ice algae living in slush water. In

230 addition, the salinity of slush water was lower than under-ice water, reflecting the

231 dilution of all slush-water components including nutrients. Therefore, it was considered 
232 that available nutrient concentration in the slush water was also low and depleted for

233 growth of ice algae. Although measures of the light intensity and nutrient concentrations

234 in slush layer were not examined in this study, these may be one of the factors

235 controlling biological productivity in slush water.

237 The temporal decrease of bromoform concentrations in slush water was correlated with 238 that of salinity when the salinity was higher than 5 (Fig. 4), suggesting that bromoform 239 concentrations in the slush water decreased because of dilution by the meltwater input

240 from the upper surface of sea ice in accordance with the increase of temperature (Figs. 2

$241 \& 3 \mathrm{~g})$. Therefore, the decrease in bromoform concentrations in slush water should

242 closely reflect the effects of dilution. Same dilution process was observed for

243 hexachlorocyclohexane in sea ice brine in the Canadian western Arctic in spring due to

244 the melting of the ice crystal matrix and replenishment of brine with seawater (Pucko et

245 al. 2010). On the other hand, at lower salinity (salinity $<5$ ), the bromoform

246 concentrations in the slush water increased with decreasing salinity (Fig. 4). It is

247 speculated that the bromoform in the slush layer tended to remain even if the large

248 volume of meltwater was added to the slush layer and diluted the bromoform because of

249 the limited gas diffusion to the atmosphere through the snow and superimposed ice

250 (Delille 2006, Nomura et al. 2010).

251

252 In contrast to the changes in slush water, bromoform concentrations in under-ice water

253 increased during the study period, tracking the increase in chl- $a$ concentrations, whereas

254 the salinity decreased (Figs. 3b, d \& f). These results for salinity suggest that the under-

255 ice water included a proportion of meltwater from the sea ice. This phenomenon is

256 similar to the process occurring in the slush water, but there are some differences in the

257 effects on bromoform and chl- $a$ concentrations. Previously, bromoform and chl- $a$

258 concentration at the bottom of the sea ice have been found to be higher than in the other

259 parts of sea ice (Sturges et al. 1997). During ice melting, the impurities in sea-ice brine

260 channels are flushed out before the melting of the ice itself, therefore these components

261 were added to the under-ice water with meltwater. The temporal changes of each

262 component in under-ice water reflect the input of the high-bromoform and chl- $a$, low- 
salinity meltwater during the study period (Figs. 3b, $d \&$ f). These changes would be

264 also enhanced by the horizontal advection of under-ice water from offshore that accumulates in Lützow-Holm Bay (Ohshima et al., 1996).

\section{Conclusions}

Bromoform concentrations in slush-layer water in Antarctic fast ice were measured during the seasonal warming in Lützow-Holm Bay. Mean bromoform concentration was $5.5 \pm 2.4 \mathrm{pmol} \mathrm{l}^{-1}$, which was lower than that of the under-ice water $\left(10.9 \pm 3.5 \mathrm{pmol}^{-}\right.$ $\left.{ }^{1}\right)$. Temporal decrease in bromoform concentrations and salinity with increasing in temperature of the slush water, suggesting that bromoform concentrations in the slush water decreased because of dilution by the meltwater input from the upper surface of sea ice in accordance with the increase of temperature. However, at lower salinity of slush water (salinity $<5$ ), the bromoform concentrations in the slush water increased with decreasing salinity. It is speculated that the bromoform in the slush layer tended to remain even if the large volume of meltwater were added to the slush layer and diluted bromoform in slush water because of the limited gas diffusion to the atmosphere through the snow and superimposed ice (Delille 2006, Nomura et al. 2010).

In contrast to the changes in slush water, bromoform concentrations in under-ice water increased during the study period, tracking the increase in chl- $a$ concentrations, whereas the salinity decreased. These results suggest that the temporal changes of each component in under-ice water reflect the input of the high-bromoform and chl- $a$, lowsalinity meltwater during the study period.

Acknowledgements

292 We thank Mr. H. Shinagawa, Dr. S. A. Chavanich, Mr. H. Shimoda and all the members 293 of the $51^{\text {st }}$ Japanese Antarctic Research Expedition (JARE-51) for their support in the 
294 field. We also thank Prof. T. Odate, Dr. Y. Yokouchi, Dr. G. Hashida and Dr. T. Iida for 295 their useful comments and for providing the measurement device (purge-and-trap GC296 MS).

297

298

299 
ACKLEy, S.F., Lewis, M.J., Fritsen, C.H. \& XIE, H. 2008. Internal melting in Antarctic sea ice: Development of "gap layers”. Geophysical Research Letters, 35, L11503, doi:10.1029/2008GL033644.

305

Baker, J.M., Reeves, C.E., Nightingale, P.D., Penkett, S.A., Gibb, S.W. \& Hatton, A.D. 1999. Biological production of methyl bromide in the coastal waters of the North Sea and open ocean of the northeast Atlantic. Marine Chemistry, 64, 267-285.

309

CARPenter, L.J., WeVill, D.J., PAlmer, C.J. \& Michels, J. 2007. Depth profiles of

311 volatile iodine and bromine-containing halocarbons in coastal Antarctic waters, Marine

312 Chemistry, 103, 227-236.

313

314 Delille, B. 2006. Inorganic carbon dynamics and air-ice-sea $\mathrm{CO}_{2}$ fluxes in the open 315 and coastal waters of the Southern Ocean. Ph. D. thesis, Univ. of Liége, Liége, Belgium, $316 \quad 1-297$.

318 HaAs, C., Thomas, D.N. \& BAREISS, J. 2001. Surface properties and processes of perennial Antarctic sea ice in summer. Journal of Glaciology, 47, 613-625.

Kattner, G., Thomas, D.N., HaAs, C., Kennedy, H. \& Dieckmannm, G.S. 2004. Surface ice and gap layers in Antarctic sea ice: highly productive habitats. Marine Ecology Progress Series, 277, 1-12.

KLICK, S. \& ABRAHAMSSON, K. 1992. Biogenic volatile iodated hydrocarbons in the ocean. Journal of Geophysical Research, 97(C8), 12683-12687.

328 Nomura, D., InOue, Y.H., Toyota, T. \& Shirasawa, K. 2010. Effects of snow, snowmelting and re-freezing on air-sea ice $\mathrm{CO}_{2}$ flux. Journal of Glaciology, 56, 262-270. 
331 Ohshima, K.I., Takizawa, T., Ushio, S. \& KawAmURA, T. 1996. Seasonal variations of 332 the Antarctic coastal ocean in the vicinity of Lützow-Holm Bay. Journal of Geophysical 333 Research, 101, 20617-20628.

335 Ooki, A. \& Yokouchi, Y. 2011a. Determination of Henry's law constant of halocarbons 336 in seawater and analysis of sea-to-air flux of iodoethane $\left(\mathrm{C}_{2} \mathrm{H}_{5} \mathrm{I}\right)$ in the Indian and

337 Southern oceans based on partial pressure measurements. Geochemical Journal, 45, el338 e7.

340 Ooki, A. \& YoKouchI, Y. 2011b. Dichloromethane in the Indian Ocean: Evidence for 341 in-situ production in seawater. Marine Chemistry, doi:10.1016/j.marchem.2011.01.001, 342 In press.

343

344 Papadimitriou, S., Thomas, D.N., Kennedy, H., Kuosa, H. \& Dieckmann, G. S. 2009.

345 Inorganic carbon removal and isotopic enrichment in Antarctic sea ice gap layers during 346 early austral summer. Marine Ecology Progress Series, 386, 15-27.

PARSONS, T.R., TAKAHASHI, M. \& HARgRAVE, B. 1984. Biological oceanographic processes, 3rd ed. 330 pp. Oxford, Pergamon Press.

350

Pucko, M., Stern, G.A., MAcdonald, R.W. \& BARBer, D.G. 2010. $\alpha$ - and $\gamma$ -

352 Hexachlorocyclohexane measurements in the brine fraction of sea ice in the Canadian

353 High Arctic using a sump-hole technique. Environmental Science \& Technology, 44, $3549258-9264$.

356 Quack, B. \& Wallace, D.W.R. 2003. Air-sea flux of bromoform: Controls, rates, and 357 implications. Global Biogeochemical Cycles, 17, 1023, doi:10.1029/2002GB001890.

359 Sturges, W.T., CotA, G.F. \& Buckley, P.T. 1992. Bromoform emission from Arctic 360 ice algae. Nature, 358, 660-662. 
362 Sturges, W.T., Sullivan, C.V., Schnell, R.C., Heidt, L.E. \& Pollack, W.H. 1993.

363 Bromoalkane production by Antarctic ice algae. Tellus, 45B, 120-126.

364

365 Sturges, W.T., Cota, G.F. \& BuckLey, P.T. 1997. Vertical profiles of bromoform in

366 snow, sea ice, and seawater in the Canadian Arctic. Journal of Geophysical Research, 367 102(C11), 25073-25083.

368

369 SUZUKI, R., \& ISHIMARU, T. 1990. An improved method for the determination of

370 phytoplankton chlorophyll using N,N-dimethylformamide. Journal of the

371 Oceanographical Society of Japan, 46, 190-194.

372

373 Yokouchi, Y., Taguchi, S., Saito, T., Tohjima, Y., Tanimoto, H. \& Mukai, H. 2006.

374 High frequency measurements of HFCs at a remote site in east Asia and their

375 implications for Chinese emissions. Geophysical Research Letters, 33, L21814,

376 doi:10.1029/2006GL026403.

377

378 Zemmelink, H.J., Hintsa, E.J., Houghton, L., DaceY, J.W.H. \& Liss, P.S. 2008. DMS

379 fluxes over the multi year ice of the western Weddell Sea. Geophysical Research

380 Letters, 35, L06603, doi:10.1029/2007GL031847.

381

382

383 


\section{Figure captions}

386 Fig 1 Map showing the location of sampling area in Lützow-Holm Bay, Eastern

387 Antarctica.

389 Fig 2 Time series of daily mean air temperatures at the sampling station. Gray band indicates the sampling period.

392 Fig 3 Time series values for (a, b) bromoform concentration, (c, d) chl- $a$ concentration,

393 (e, f) salinity and (g, h) temperature, for slush water (a, c, e \& g) and under-ice water (b,

394 d, f \& h). Error bars for slush water data (a, c, e \& g) indicate the range of duplicate

395 measurements. Error bars are only shown if they extend beyond the symbols.

397 Fig 4 Relationships between salinity and bromoform concentrations in slush water.

398 Solid and dashed line represents the linear regression line. Bromoform concentrations in 399 slush water were correlated with the salinity in slush water for salinity $>5(r=0.93, P$

$400<0.0001, n=12)$ and for salinity $<5(r=0.64, P<0.046, n=10)$.

401

402

403 Table captions

404

405 Table 1. Mean, minimum, Q1 (25 percentile), median, Q3 (75 percentile) and maximum 406 of bromoform and chl- $a$ concentrations, and salinity and temperature for slush water $407(\mathrm{n}=22)$ and under-ice water ( $\mathrm{n}=30$ to 32$)$ as measured during the study period. 


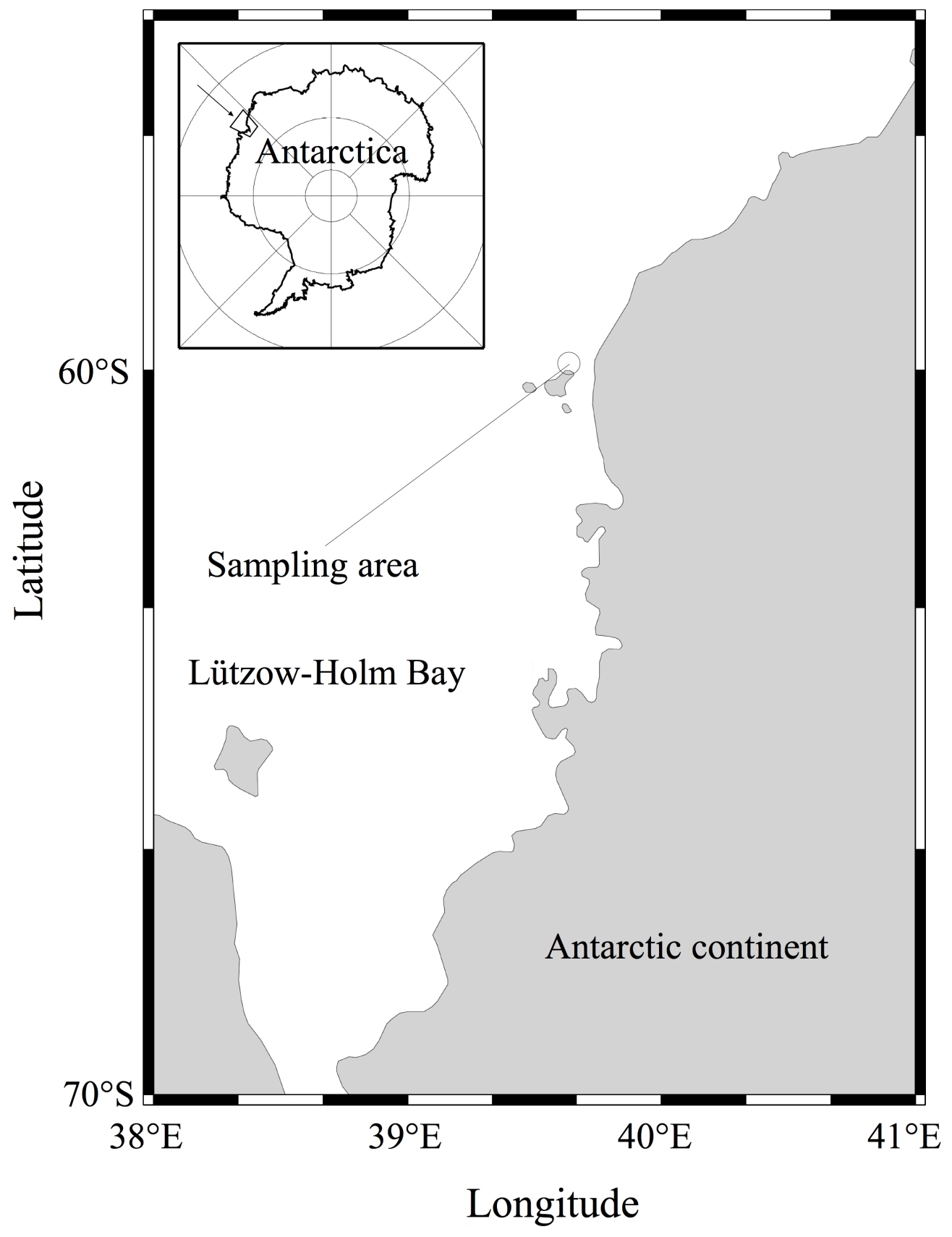

Figure 1. Nomura et al. 


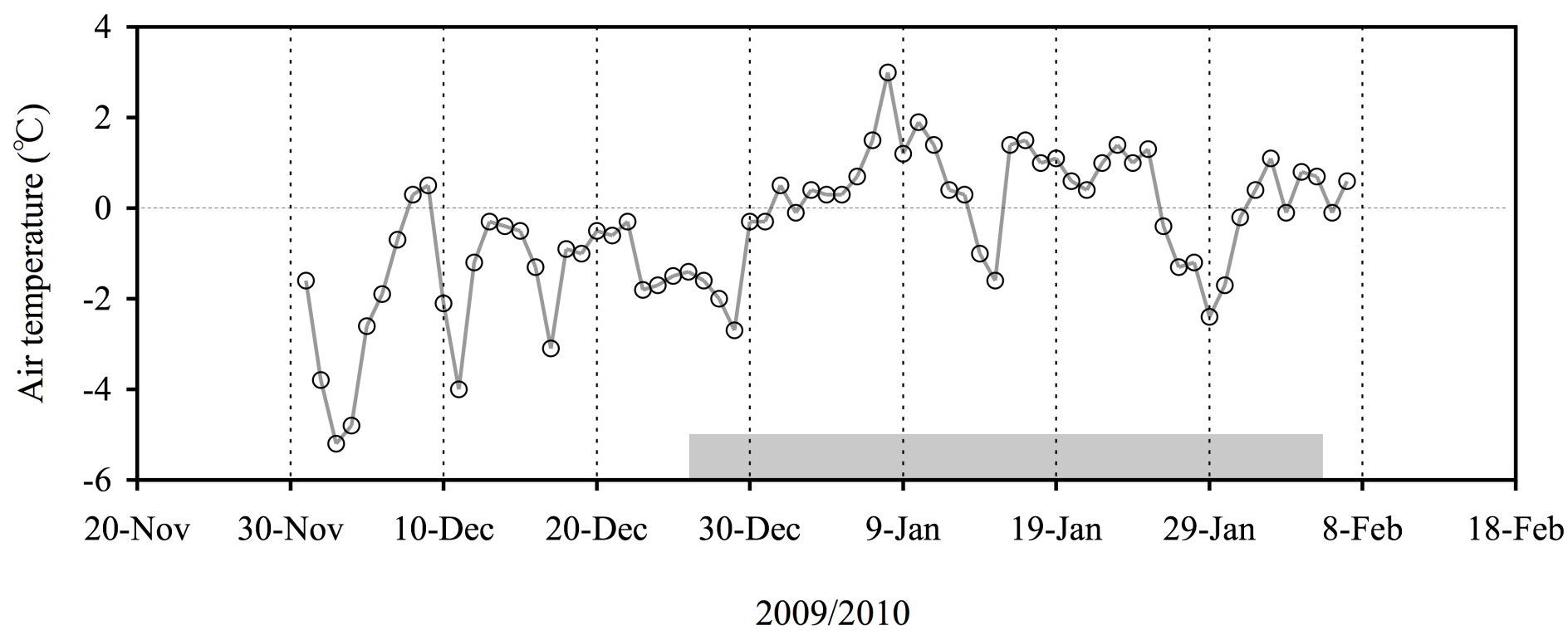

Figure 2. Nomura et al. 
Slush water
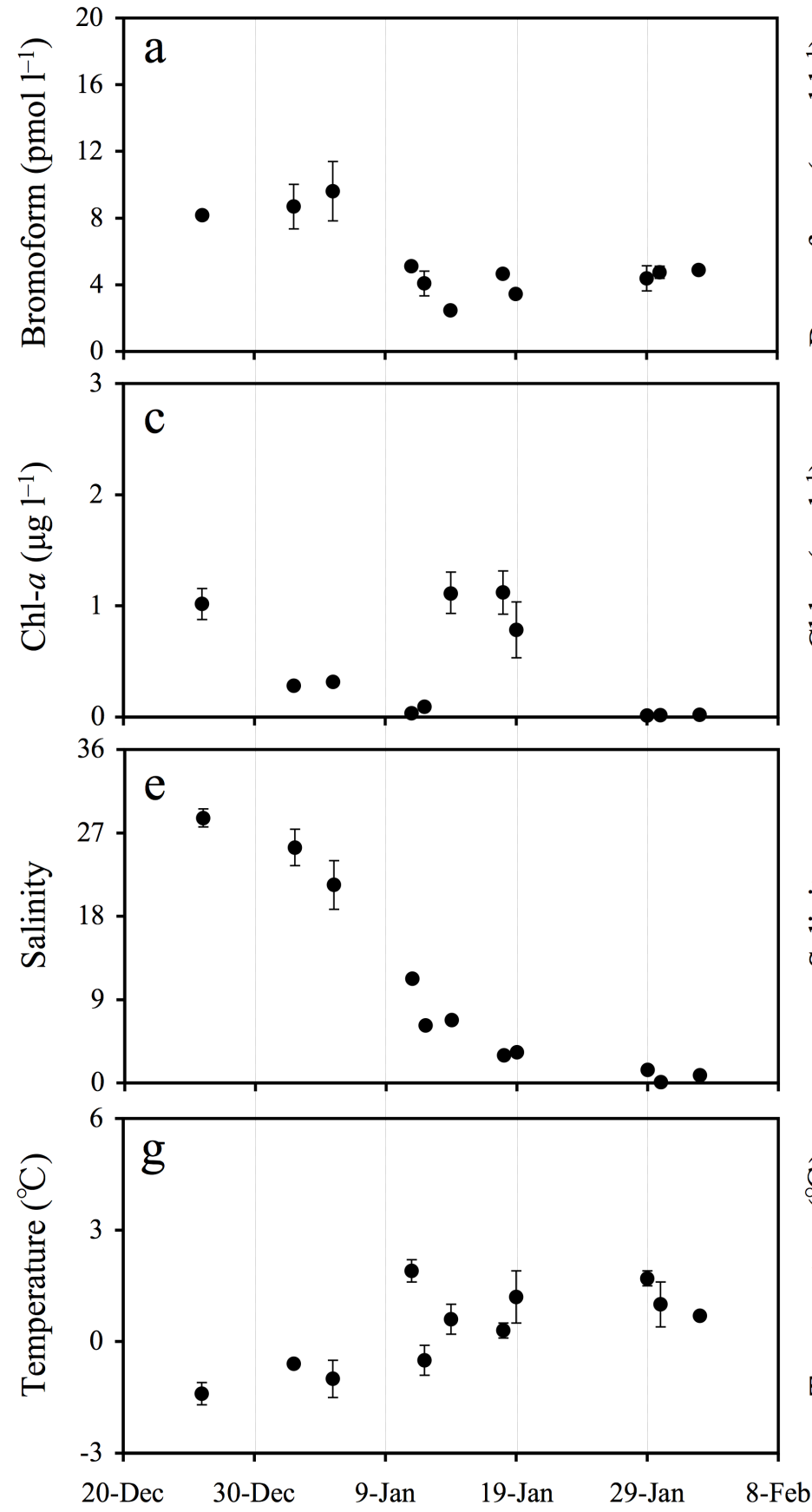

$2009 / 2010$
Under-ice water
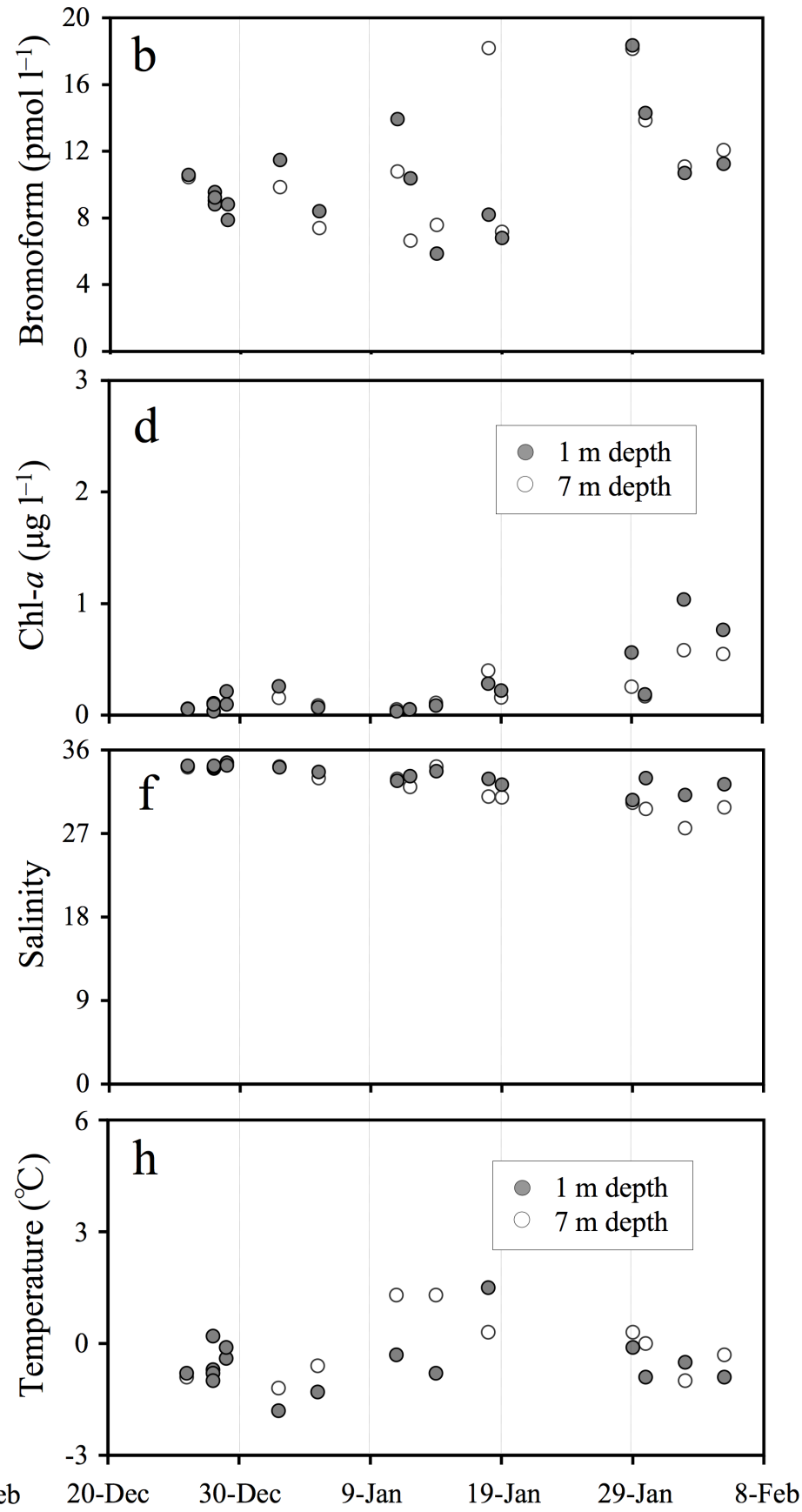

2009/2010

Figure 3. Nomura et al. 


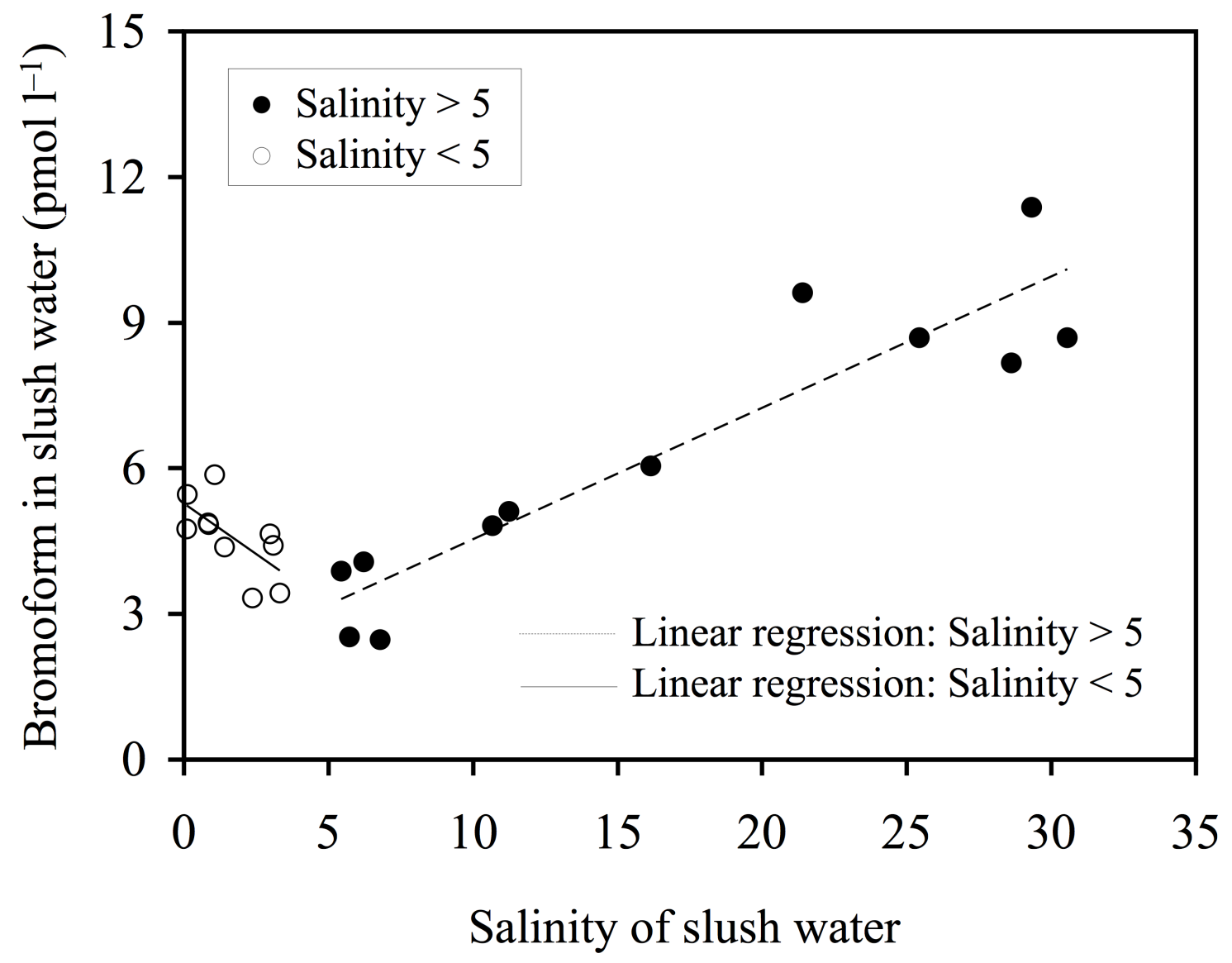

Figure 4. Nomura et al. 
Table 1. Mean, minimum, Q1 (25 percentile), median, Q3 (75 percentile) and maximum of bromoform and chl- $a$ concentrations, and salinity and temperature for slush water $(\mathrm{n}=22)$ and under-ice water $(\mathrm{n}=30$ to 32$)$ as measured during the study period.

\begin{tabular}{llcccccc}
\hline Sample & Parameter & Mean & Minimum & Q1 & Median & Q3 & Maximum \\
\hline Slush water & Bromoform $\left(\mathrm{pmol} \mathrm{l}^{-1}\right)$ & 5.5 & 2.5 & 4.2 & 4.8 & 6.0 & 11.4 \\
& Chl- $a\left(\mu \mathrm{g}{ }^{-1}\right)$ & 0.4 & 0.0 & 0.0 & 0.2 & 0.7 & 1.1 \\
& Salinity & 9.7 & 0.1 & 1.6 & 5.6 & 14.9 & 30.6 \\
& Temperarure $\left({ }^{\circ} \mathrm{C}\right)$ & +0.5 & -1.9 & -0.4 & +0.6 & +1.3 & +2.6 \\
& & & & & & & \\
Under-ice water & Bromoform $\left({\left.\mathrm{pmol} \mathrm{I}^{-1}\right)}^{*}\right.$ & 10.9 & 5.9 & 8.4 & 10.4 & 12.5 & 18.3 \\
& Chl- $a\left(\mu \mathrm{g} \mathrm{l}^{-1}\right)$ & 0.2 & 0.0 & 0.1 & 0.1 & 0.3 & 1.0 \\
& Salinity & 32.5 & 27.6 & 31.1 & 32.9 & 34.1 & 34.7 \\
& Temperarure $\left({ }^{\circ} \mathrm{C}\right)$ & -0.4 & -1.8 & -0.9 & -0.7 & -0.1 & +1.5 \\
\hline
\end{tabular}

